\title{
Students' Perception Towards Pancasila and Civic Education Learning Based on Living Values Education
}

\author{
Maya Kusmayanti ${ }^{1, *}$, Kokom Komalasari $^{2}$, Tubagus Saputra ${ }^{3}$ \\ ${ }^{1,2,3}$ Universitas Pendidikan Indonesia, Bandung, Indonesia \\ *Corresponding author.Email: mayakusmayanti@upi.edu
}

\begin{abstract}
Learning Pancasila and Civic Education based on Living Values Education is a positive innovation step as an attempt to strengthen the values of life so that students will have anti-radicalism attitude. The aim of this study is to find out how students perceive the learning of Pancasila and Civic Education based on Living Values Education at SMKN 13 Bandung. The approach applied in this study is descriptive-quantitative with the method of quasi-experiment. The data collection technique used is research questionnaire in a form of Likert scale as a tool to measure the attitude, opinion or perception of someone towards certain social phenomenon. The findings of this study indicate that students' perception towards the learning of Pancasila and Civic Education based on Living Values Education at SMKN 13 Bandung are 89\% of students are very tolerant, $60.5 \%$ of students always uphold the value of peace, $67.6 \%$ of students are really care about their surroundings, have high sense of empathy, and $57 \%$ of students aware of their obligations to God and implement Pancasila and Civic Education taught at school. Thus, it can be concluded from the average student that the perception of students at SMKN 13 Bandung towards learning Pancasila and Civic Education based on living values education is good, so the actualization needs to be continued.
\end{abstract}

Keywords: Living Values Education, Pancasila and Civic Education.

\section{INTRODUCTION}

The Indonesian national country has a national identity as a tolerance, religion, and peace-loving nation as the teachings in Pancasila. However, due to the current pandemic global that is happening has given birth to radicalism behavior in society that is precisely contrary to Pancasila as ideology, state policy, and the nation's outlook on life, therefore, strengthening national identity is important in the framework of the existence of the nation's identity.

Education is actually a solution to all the problems faced by the Indonesia today, because through education the national goals of the Indonesian nation can be realized. Problems in the field of education are so diverse, ranging from educational inequality, the high cost of education, educators and education personnel who are lack of innovation and many other problems. Nevertheless, there is another issue that should be taken into consideration, namely the problem of the emergence of the seeds of radicalism among students.

It can said that the substance of radicalism is; (1) radical sects or ideologies, (2) sects or those oriented towards social and political revolution or renewal through violence or mass, and (3) extreme character in politics streams. radicalism as radical ideology or stream in politics, which usually demands drastic social changes through violence or extremism, and it can be divided into 2 (two) levels. The first level is the level of thought in a form of radicalism, which consists of discourse, concept, and ideas that are still being discussed and essentially support the use of violent means to achieve goals. The second level is the level of action in the form of imposing opinions in unconstitutional ways, it can even be in the form of mass mobilization actions for the interests of certain groups that lead to on social conflict [1].

The penetration of radicalism ideology into students has certainly become a concern because it will cause intolerance in students which results in the growth of other violent phenomena such as motorcycle gangs, brawls between students, fights, bullying and other acts of violence.

Based on data obtained from the BNPT (National Counter-Terrorism Agency) the involvement of 
teenagers aged 18-30 years in terrorism activities reached 80 percent of the 600 suspected terrorists who had been arrested. Another phenomenon is the involvement of children aged 8-18 years in the bomb explosion in Surabaya that occurred around the year of 2018. This data shows that the recruitment of terrorists has targeted school age children. Another finding in the field of schooling is that there are children who are indoctrinated with radicalism who do not want to respect the red and white flag because they believe it can bring Shirk. This is clearly a worrying fact, because it can become the seed of radicalism.

As educator, of course, this cannot be tolerated. School as a place to shape the character of students must be able to contribute significantly in fostering attitudes and love for the nation to students. Through the educational process, the domains of knowledge, skills and attitudes of students can develop and integrate, this will also develop the personality and self-realization of students in schools which will become important instruments in exploring and realizing educational orientation. This is because schools are professional, formal and communicative organizations so that they have the power to create an educated nation, especially with the support of increasingly comprehensive and integrative scientific disciplines, which will of course streamline the educational goals of schools, which are maximized not only on knowledge but also on character and expertise [3].

School as an educational environment is a place for the development of life values for the younger generation. It is because, through the participation of schools, students can develop life values which in turn will be attached to the character of the students themselves. Pancasila and Civic Education are the leading sectors in character education in Indonesia to create a good citizen with the characteristics of having a patriotic attitude, tolerant, loyal to the nation and state, religious, democratic, and true Pancasila [4].

With this orientation, it can be emphasized that the learning of Pancasila and Civic Education becomes a learning that is endowed with concepts and practices regarding character and values. Therefore, to make it happen, it is necessary to find an effective character education model to transform the character of students. One of the educational models that can be offered as an alternative is character education which contains living values and character education based on school culture [5].

Based on this, the model of character education that is considered suitable for developing anti-radicalism is through living values education. The model has become an educational program on values by the United Nations through UNICEF which provides a special program for educators and volunteers to help the younger generation to be able to explore as well as to strengthen individual and social key values through a variety of positive activities and praxis. Needless to say, the values of life that are prioritized by LVE lead to: respect, peace, love, happiness, responsibility, collaboration, honesty, tolerance, humbleness, freedom, integration and simplicity. The various activities carried out focus on: accommodating the substance of reflection, comprehensive imagination, strengthening flexibility and focus, creating expressive art, strengthening social skills, and transforming values and even culture [5]. Based on this, the model of character education that is considered suitable for developing anti-radicalism is through living values education. The model is an education program on values by the United Nations through UNICEF which presents a special program for educators and volunteers to help the younger generation to be able to explore as well as to strengthen individual and social key values through a variety of positive activities and praxis. Of course the values of life that are prioritized by LVE lead to: respect, peace, love, happiness, responsibility, collaboration, honesty, tolerance, humility, freedom, integration and simplicity. The various activities carried out focus on: accommodating the substance of reflection, comprehensive imagination, strengthening flexibility and focus, creating expressive art, strengthening social skills, and transforming values and even culture [6]. Thus, the teacher accommodates the learning of the value of life for students which leads to the habituation of values, personality as well as social values to become the standard of living for students. Of course the transformation of values about life in students becomes the core of learning about the value of life [7].

Living Values Education is considered to be the perfect idea or concept to answer the problem of antiradicalism in schools, especially at SMK Negeri 13 Bandung. This is in accordance with the vision of SMK Negeri 13 Bandung, which is to create graduates who have noble character, competence and competitiveness at the international level. From this vision, it can be seen that SMK Negeri 13 Bandung puts forward the affective side, which is wanting its students to have noble character and good personalities. The selection of SMK Negeri 13 Bandung as the research location is based on strong reason; researchers have seen various phenomena that lead to acts of radicalism such as the presence of students who are exposed to radical sects through religious activities provided by alumni through extracurricular activities, the existence of students who fight and the most is an act of bullying both verbally and non-verbally, because those activities will hinder the efforts of realizing a humanist school, where students grow and develop in line with their interests and talents. 
This violence certainly has an impact on the birth of a school reality that is not encouraging and even not friendly to children, so that it damages both the physical and spiritual aspects of students.

In order to deal with this issue, it is considered to be important to shape the mental and behavior of students who are pro to peace and humanity. Through a step called the actualization of the learning of Pancasila and Civic Education based on living values education, therefore, this study highlights how students perceive the learning of Pancasila and Civic Education based on living values education at SMKN 13 Bandung can be an innovative formulation that can be offered in order to counteract radicalism among students of SMKN 13 Bandung.

\section{THEORETICAL REVIEW}

\subsection{Living Values Education}

Living Values Education is one of the developments of a character education learning model that emphasizes the principles of fun learning in the form of conflict resolution exercises, discussions, artistic activities, games, communication exercises, concept maps, creative writing, role playing, imagination exercises, relaxation and concentration [5]. The existence of living values education has provided a space of choice for civic educators to teach and develop anti-radicalism behavior and strengthen national identity as a peace-loving nation state.

\subsection{Anti-Radicalism Attitude}

The attitude of anti-radicalism can be learned through educational efforts. Anti-radicalism education through the learning process carried out by teachers is expected to build a peaceful and tolerant society [8]. This then confirms that anti-radicalism education can be implemented in the school environment by incorporating anti-radical values in the learning process and applying anti-radical values to the school environment through empathy and compassion [9]. Thus, the attitude of antiradicalism is a manifestation of the behavior of citizens who always prioritize peaceful approach, democratic, compassion and human values. Through the learning of Pancasila and civic education becomes one of the vehicles to foster anti-radicalism behavior

\section{METHOD}

Researchers apply a quantitative approach with a quasi-experimental method in this study. Quasiexperimental method is used to determine the possible cause and effect between the independent and dependent variables, where the author wants to know students' perceptions on how learning Pancasila and Civic Education based on living values education at SMKN 13 Bandung can contribute to strengthening students' antiradicalism attitudes.

The research instrument applied in this study was a questionnaire. Questionnaire is a data collection technique that is done by giving a set of questions or written statements to respondents to answer. Questionnaires are an efficient data collection technique if the researcher knows exactly the variables to be measured and knows what to expect from the respondents [10]

In order to find out students' perceptions on learning Pancasila and Civic Education based on living values education, as well as about students' anti-radicalism attitudes at SMK Negeri 13 Bandung, the researchers used a Likert scale, which is a measurement used to measure a person's attitudes, opinions, or perceptions about social phenomena. Generally, the alternative answers to the Likert scale model questionnaire consist of 5 alternative answers, but in this study only four alternative categories were used, as listed in table 3.1 below [11]:

Table 3.1 Likert Scale

\begin{tabular}{|l|c|}
\hline Alternative Answers & Score \\
\hline Always (SL) & 4 \\
\hline Frequently (SR) & 3 \\
\hline Occasionally (KD) & 2 \\
\hline Never (TP) & 1 \\
\hline
\end{tabular}

The steps for calculating the percentage are as follows:

a. Calculating frequency

b. Calculating percentage $(\mathrm{P})$ of answers using the formula:

$\mathrm{P}=\mathrm{F} / \mathrm{N} \times 100 \%$

Note:

$\mathrm{P} \quad=$ Percentage of answers

$\mathrm{F} \quad=$ Number of frequency of each alternative answer

$\mathrm{N}=$ Number of sample

$100 \%=$ Fixed number

c. Interpretation of Research Findings

To provide interpretation of the percentage obtained, previously calculated the mean for each statement using the mean formula proposed by Creswell (2013)[2] as follows:

Where : $\mathrm{M}=$ Mean (average value)

$\sum=$ Express the amount

$\mathrm{Fi}=$ Frequency of answers

$\mathrm{xi}=$ Score of answer choices

After obtaining the percentage of respondents' answers, they are then given an interpretation or assessment of the research results. Researchers use the interpretation method as shown in table 3.2 below [12] : 
Table 3.2 Category of Percentage Value

\begin{tabular}{|c|c|c|}
\hline No. & $\begin{array}{c}\text { Percentage Limit } \\
\text { Interval }\end{array}$ & $\begin{array}{c}\text { Rating } \\
\text { Category }\end{array}$ \\
\hline 1. & $0-20 \%$ & Very Low \\
\hline 2. & $21-40 \%$ & Low \\
\hline 3. & $41-60 \%$ & Average \\
\hline 4. & $61-80 \%$ & High \\
\hline 5. & $81-100 \%$ & Very High \\
\hline
\end{tabular}

\section{RESULT AND DISCUSSION}

In this study, the corridors of living values education adopted are the values of tolerance, peace, love, and religion. These values are characteristic of the values of life that are put forward in the ethics of social habits at SMKN 13 Bandung, therefore, how students perceive the learning of Pancasila and Civic Education that adopt the values of tolerance, peace, love, and religion as the substance of living values are actualized at SMKN 13 Bandung as a core activity in schools in an effort to prevent student radicalism.

The occurrence of radicalism in the reality of the educational domain, especially in schools, has become serious concern, thus, it requires anti-radicalism education efforts. These substances can be implemented by educators through the context of studying and learning, to shape the mental and behavior of students who protect peace and humanity. Studying and learning is an activity where there is a process of change in knowledge, skills, habituation, and attitudes that are expected to realize various forms of efforts to improve skills [13]. In this context that anti-radicalism education in the school environment requires love and sympathy, of course values against radicalism need to be integrated into the learning and activities of students in schools. The values of anti-radicalism are substantially appropriate to be taught through Pancasila and Civic Education which are based on the substance of Living Values Education [8].

Based on the questionnaire that have been distributed to respondents, 64 students in class XII AK 4 and XII AK 5. The questionnaires given consist of 16 questions, with the gradation of each instrument item using a Likert that has gradation from very positive, which can be in the form of words:
a. Always : :SL
b. Frequently :SR
c. Occasionally $\quad: \mathrm{KD}$
d. Never : TP

From the gradation of the answers, a score for each item of the questionnaire is compiled, namely:

For positive statement, the scores given are as follow: a. SL : 4

b. SR : 3

c. KD: 2

d. TP : 1

For negative statement, the scores given are as follow:

a. SL : 1

b. SR : 2

c. $\mathrm{KD}: 3$

d. TP : 4

After the data collected, the researchers processed it in the form of a frequency distribution table which was equipped with a percentage with the formula:

Note:

$$
\text { Formula } \mathrm{P}=\frac{F}{N} \mathrm{X} 100 \%
$$

$\mathrm{P}=$ Percentage number

$\mathrm{F}=$ Frequency being searched the percentage

$\mathrm{N}=$ Number of samples

Based on this, students' perceptions on learning Pancasila and Civic Education based on living values education can be explained that the results of the research on Student Perceptions of Learning Pancasila and Civic Education Based on Living Values Education at SMKN 13 Bandung were measured using a questionnaire given to 64 respondents, students of SMKN 13 Bandung obtained from two classes, which are the experimental class and the control class. In this research, there are indicators used to make the points of statement, namely tolerance, peace, love and religion. These values were chosen because they are the hallmark of the identity of SMKN 13 Bandung.

Based on the analysis of descriptive-quantitative calculated by using SPSS 25, the result obtained:

\section{a]. Tolerance Indicator}

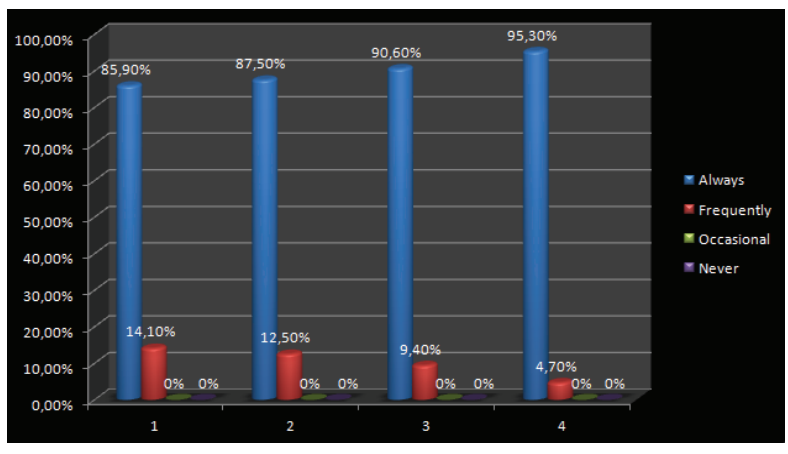

Figure. 1 Tolerance Indicator

In the tolerance indicator, from the 4 questions asked, the average student always answered is $89 \%$, which means that students are very tolerant of differences in the surrounding environment and apply Pancasila and Civic education that is taught. The use of discussion methods in the learning of Pancasila and civic education provides an opportunity for students to 
have a tolerance behavior in terms of listening to the opinions of others. Students also learn about how to respond appropriately and wisely.

\section{b]. Peace Indicator}

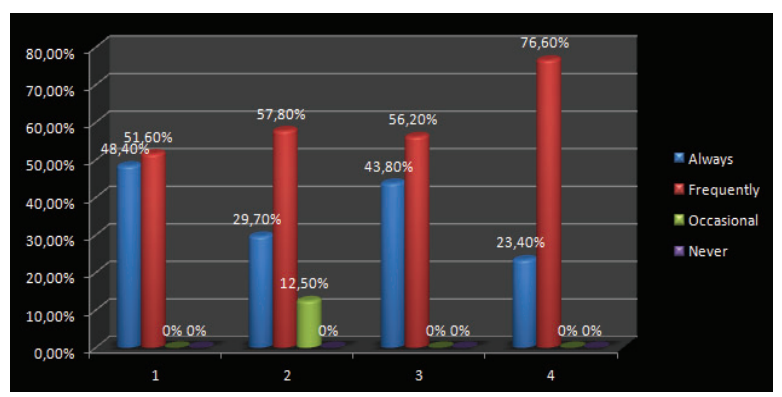

Figure. 2 Peace Indicator

In the indicator of peace, from the 4 questions asked, the average student answered frequently is $60.5 \%$, which means that students highly respect the peace that exists in the surrounding environment and apply the Pancasila and Civic education that is taught. Accustoming students to organize and prepare the room to be used to learn so that they feel comfortable and orderly in learning behavior has supported it. Then, the habituation to pause for a moment and enjoy the atmosphere that occurs around them makes the student feel calmer. They are taught to argue with a calm and accountable bearing.

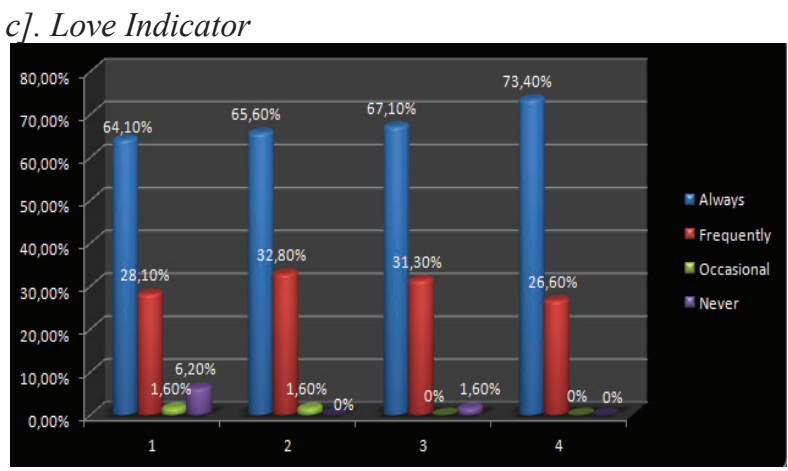

Figure. 3 Love Indicator

In the love indicator, of the 4 questions asked, the average student answered always is $67.6 \%$, which means that students really care about their surroundings, have a high sense of empathy and apply the Pancasila and Civic education that is taught. The habituation of smiles, greetings, and greetings in the learning process makes students have an attitude of affection towards others. Through a conflict resolution approach students learn about how to behave well in dealing with a problem. They become more compassionate to other students who are in trouble.

\section{d]. Religious Indicator}

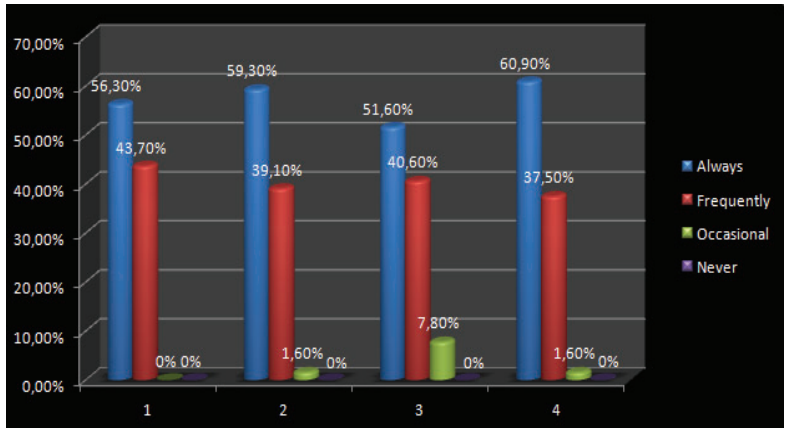

Figure. 4 Religius Indicator

In religious indicators, out of the 4 questions asked, the average student answered always is as much as $57 \%$, which means that students are aware of their obligations to God and apply the Pancasila and Civic education taught. Teachers always accustom students to pray before and after learning is done and insert religious messages in the sentences of the learning material message presented.

Referring to the above conditions, the learning of Pancasila and Civic Education based on living values education has a significance for strengthening students' anti-radicalism attitudes at SMKN 13 Bandung. So that, Pancasila and Civic Education are the leading sectors in character education in Indonesia to create a good citizen with the characteristics of having a patriotic attitude, tolerant, loyal to the nation and state, religious, democratic, and true Pancasila [4].

\section{CONCLUSION}

In the pandemic situation has given birth to a challenge and response how to civic education view respond to the situation and attitudes of radicalism among students in an effort to strengthen national identity. Through learning pancasila education and citizenship based on living values education becomes an alternative among other ways that can be done by civic educators. Students' perception of Pancasila and civic education learning based on living values education at SMKN 13 Bandung is positive, therefore, this actualization effort must continue to be sustainable to strengthen national identity as an anti-radicalism student.

\section{REFERENCES}

[1] Munip, A. (2012). Menangkal Radikalisme Agama di Sekolah. Jurnal Pendidikan Islam. Volume I, Nomor 2, Desember 2012/1434

[2] Creswell, J.W. (2013). Research Design Pendekatan Kualitatif, Kuantitatif dan Mixed. Yogyakarta : Pustaka Pelajar 
[3] Daryono, M. (2008). Pengantar Pendidikan Pancasila dan Kewarganegaraan. Jakarta : PT Rineka Cipta

[4] Somantri, N. (1976).Metode Mengajar Civics. Jakarta: Erlangga

[5] Komalasari, K .dan Sarifudin, D. (2017). Pendidikan Karakter Konsep dan Aplikasi Living Values Education. Bandung : Refika Aditama

[6] Tillman, D. (2004). Living Value: Activities for Children Ages 8-14. Jakarta : PT Gramedia Widiasarana Indonesia.

[7] El Mubarok, Z. (2009). Membumikan Pendidikan Nilai; Mengumpulkan yang Terserak, Menyambung yang Terputus, dan Menyatukan yang Tercerai. Bandung: Penerbit Alfabeta.

[8] Wiyani, N.A. (2013). Pendidikan Agama Islam Berbasis Anti Teroris di SMA. Jurnal Pendidikan Islam. Vol. 2, No.1, diunduh pada tanggal 20 Juli 2020

[9] Alhairi. (2017). Pendidikan Anti Radikalisme: Ikhtiar Memangkas Gerakan Radikal. Jurnal Tarbawi. Vol.14, No.2 hlm. 109-122

[10] Sugiono. (2012). Metode Penelitian. Bandung: Alfabeta

[11] Riduwan. (2005). Belajar Mudah Penelitian Untuk Guru, Karyawan dan Peneliti Pemula. Bandung: Alfabeta

[12] Arikunto, S. (1998). Manajemen Penelitian. Jakarta: Rineka Cipta

[13] Komalasari, S. (2010). Pembelajaran Kontekstual. Bandung: Refika Aditama 